\title{
潮流エネルギ一変換のための 直立型水車に関する研究 PERFORMANCE OF VERTICAL AXIS TURBINES FOR EXTRACTING TIDAL CURRENT ENERGY
}

\author{
中村孝幸 1 ・青山善行 2 ・浦中光太 ${ }^{3}$ ・安井孝 4 ・二宮一成 4 \\ Takayuki NAKAMURA, Yoshiyuki AOYAMA, Kouta URANAKA, Takashi YASUI \\ and Takanori NINOMIYA \\ 1正会員 工博 愛媛大学大学院 理工学研究科（干790-8577 愛媛県松山市文京町 3 番) \\ 2 工博 愛媛大学大学院 理工学研究科（干790-8577 愛媛県松山市文京町 3 番） \\ 3 愛媛大学大学院 理工学研究科（干790-8577 愛媛県松山市文京町 3 番） \\ 4 今治市 総合政策部（干794-8511 今治市別宮町 1 丁目 4 番地 1 同上）
}

\begin{abstract}
In order to develop an efficient water turbine for extracting tidal current energy at Kurushima Strait in Imabari, Japan, three different types of turbine, including a Darrieus Turbine and a Savonius Turbine, have been examined experimentally. In this study, considering the multi directional streaming of tidal current at Kurushima Strait, the vertical axis turbine was adopted as a possible energy extraction device. An additional current controlling device was newly proposed to power up the extraction efficiency of the vertical axis turbine. It was found out that the additional current controlling device is very useful to increase the efficiency of the vertical turbine, typically by about three times. For the practical design of vertical axis turbine at Kurushima Strait, tidal current forces and wave forces on the vertical axis turbine were experimentally examined.
\end{abstract}

Key Words : Tidal current energy, vertical axis turbine, current controlling device, current force, wave force,

\section{1. まえがき}

近年，持続可能なエネルギーの利用に対する積極 的な取り組みを推進する政策・方針を背景に, 国内 外で潮流エネルギー利用への注目が高まり，実験お よび研究の成果が発表されてきた（例えば，Khan他 1)，経塚他 ${ }^{2}$ ）。水車（タービン）の形態としては, 羽根を取りつけた回転軸が流れ方向と平行となるか

(平行型), 直交するか（直立型）で大別される. 回転軸が流れに直交する直立型としては，サボニウ ス型あるいはダリウス型と呼ばれる形式が代表的な ものである。

本研究では, 強潮流として知られている来島海峡 を想定して，潮流エネルギーを効率的かつ安定的に 取得するための水車構造について主に実験的に検討 を行い，トルク特性あるいは動力特性を明らかにす る。このとき水車の構造は, 来島海峡では局所的な 地形の影響を受けて上げ潮と下げ潮で流向が真反対 になりにくいことなどを考慮して，流れの方向性の
影響を受けにくい直立型の水車とした。既に木方ら ${ }^{3)}$ は，来島海峡において直立型のダリウス型水車を 用いた現地実験を行い，小規模ながらも有効な潮流 発電が可能になることなどを報告している.

一方, 来島海峡は, 烇灘や安芸灘など吹送距離の 比較的長い海域に挟まれるため, 波の影響が無視で
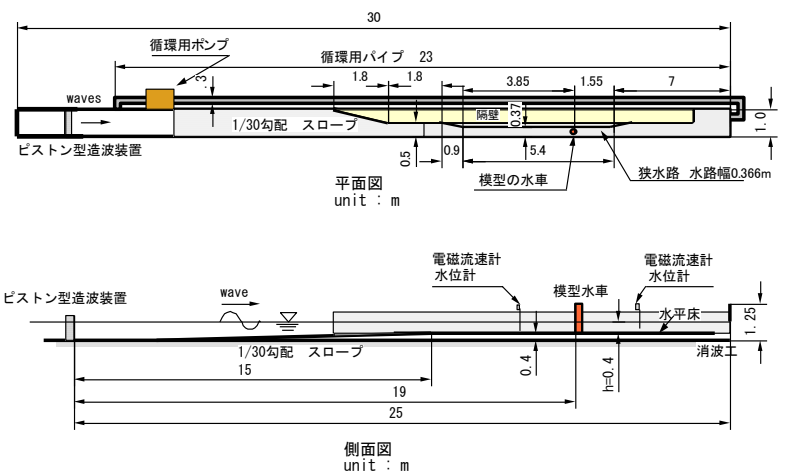

図-1 実験水槽および計測装置の配置 


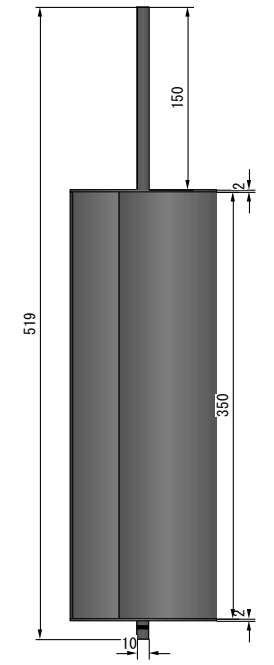

図-2 サボニウス型水車(単位 $\mathrm{mm}$ )

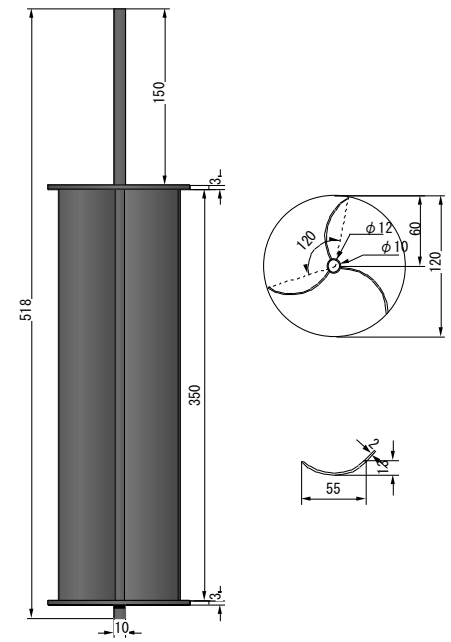

図-3 弧状3枚羽根型水車 (単位 $m m$ )

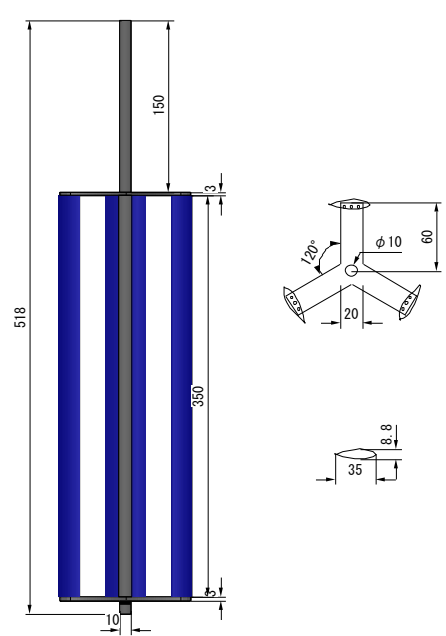

図-4 ダリウス型水車(単位mm)
きないと考えられ，水車の回転能力に及ぼす波の影 響についても部分的に検討を加えた。また，水車の 構造設計において水車に作用する潮流力および波力 の特性の把握は不可欠であり, ここでは, 流れ方向 への射影面積が大きく, 受ける流体力も最大となる と予想されるサボニウス型水車を対象にして検討を 行った

\section{2. 実験概要}

\section{（1）実験水槽}

本実験には, 愛媛大学工学部環境建設工学科の造 波機付きの回流水槽を用いた。この水路は，図-1に 示すように，長さ $30 \mathrm{~m} \times$ 幅 $1 \mathrm{~m} \times$ 深さ $1.25 \mathrm{~m}$ の規模であ る.この水路の一端には造波装置が設置してある. 水槽の両端部は大口径パイプにより結合してあり, その途中に循環用の直流ポンプ2台が設置してある. このため，水路内では波と流れを同時に発生させて， 各種の水理実験が行えるようにしてある.

水槽内には, 水平流速の増加を可能にするため, 図中に示すように, 水路幅をほぼ $1 / 3$ の $36 \mathrm{~cm}$ 程度に 狭くするように壁構造物を設けた。このとき，水路 幅を狭くすることで流れが乱されるのを軽減するた め, 水路幅を順次に2段階にわたり絞り込むように 工夫した。水路幅の絞り込みの状況は，図中に示す とおりである。潮流の模型化には，フルードの相似 則を適用し，長さの縮尺はほぼS $=1 / 30 〜 1 / 50$ を想定 した.

\section{（2）模型水車}

本実験で用いた水車は，図-2～4に示すサボニウ ス型，ダリウス型および弧状三枚羽根型の3種類で あり, いずれも水車の外径が $12 \mathrm{~cm}$, 羽根部分の高さ が35cmと一定にしてある。サボニウス型および弧状 三枚羽根型水車は羽根に作用する抗力を利用して回

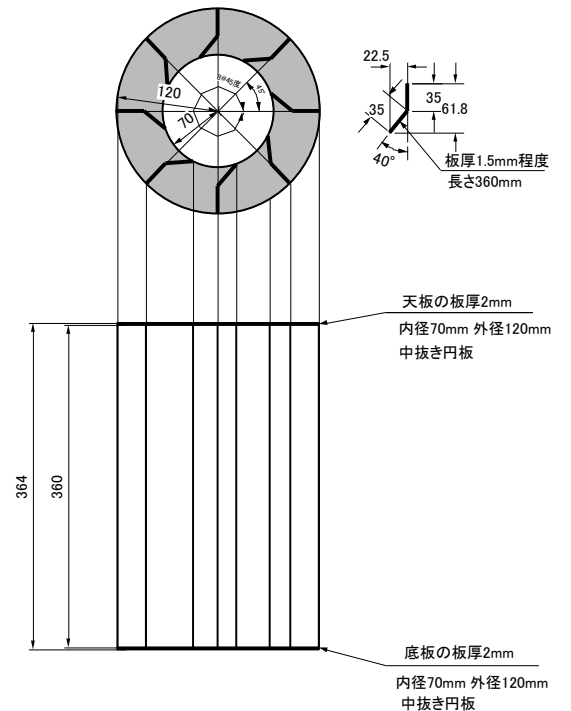

図-5 流向制御板 (中央部に水車を挿入して使用)

転トルクを得る水車で, ダリウス型水車は羽根に作 用する揚力を利用して回転トルクを得る方式である。

また，実験の途中段階において，サボニウス型お よび弧状三枚羽根型水車については流れに対する相 対的な回転数が低くなりやすいことが判明したため, これを増速するため, 図-5に示すような流向制御板 を考案し, 水車の周りに取り付ける試みを実施した。

\section{（3）実験条件}

本実験で用いた水深 $\mathrm{h}$ は $40 \mathrm{~cm}, 30 \mathrm{~cm}$ の 2 種類で, 流 速は $0.2 \mathrm{~m} / \mathrm{s} \sim 0.6 \mathrm{~m} / \mathrm{s}$ の範囲内で複数の条件を用いた。 また，入射波条件としては，現地換算で来島海峡の 近辺海域での常時波浪 (波高 $\mathrm{H}=1 \mathrm{~m}$, 周期 $\mathrm{T}=4 \mathrm{~s}$ ) および 激浪時の波浪 (波高 $\mathrm{H}=3.1 \mathrm{~m}$ ，周期 $\mathrm{T}=6.5 \mathrm{~s}$ ) を想定して， これらを含むように波条件を設定した。

実験ケースは，水車なしの予備ケースを含め，3 種類の水車に加え, 流向制御板を付加したサボニウ ス型水車と弧状 3 枚羽根型水車の計6ケースとした。 


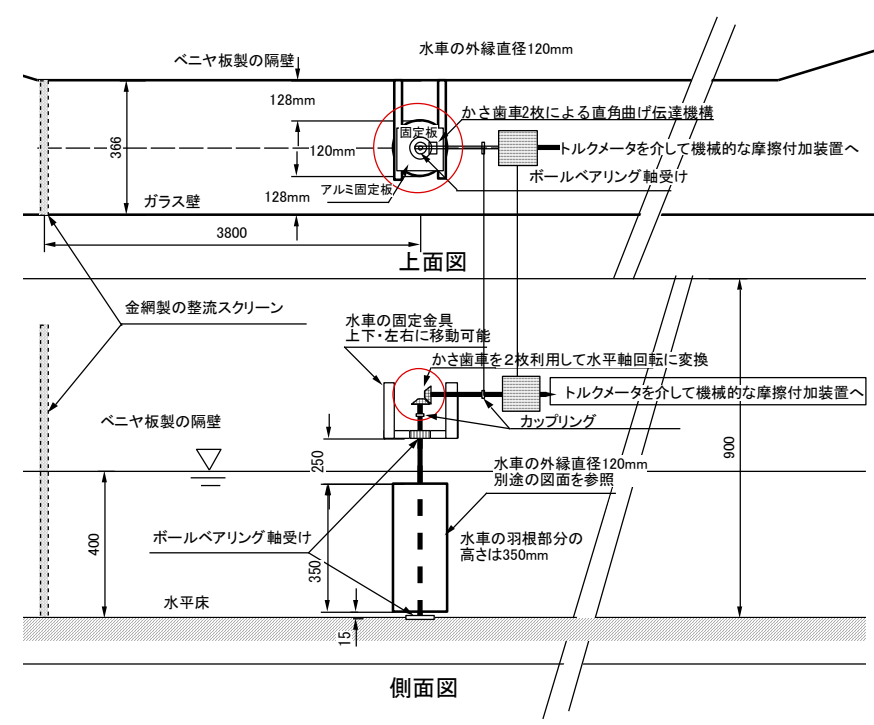

図-6 水車の設置状況およびトルクメータおよび負荷装 置との連結

このとき，発電機による負荷を近似的に再現した摩 擦負荷トルクは, 各水車の回転が止まる寸前までの 数種類を適宜に選定した。一方，水車なしの場合に ついては, 予備実験として, 狭水路での流速分布に 及ぼす水路幅の絞り込みの影響の検討を行った.

\section{（4）計測方法}

実験では，水車の上部でかさ歯車を介して水車の 軸動力を水平方向に変換しトルクメータに連結し, 各流速条件の水平流速值に固定して, トルクメータ 背後の機械的な摩擦付加装置を利用して回転負荷を 各種に変化させて, 水車回転数と作用している負荷 トルクを同時に測定した。水車とトルクメータの連 結状況を図-6に示す.なお，回転方向を鉛直より水 平へ変化させるために用いたかさ歯車は, 摩擦付加 装置に類似した負荷を生起していたため, この歯車 による負荷量についても別途に実験を行って把握し， それを考慮したパワーの算出を行った.

また，模型水車に作用寸る定常流体力（潮流力） と作用波力の測定は，水車の射影面積が流れの方向

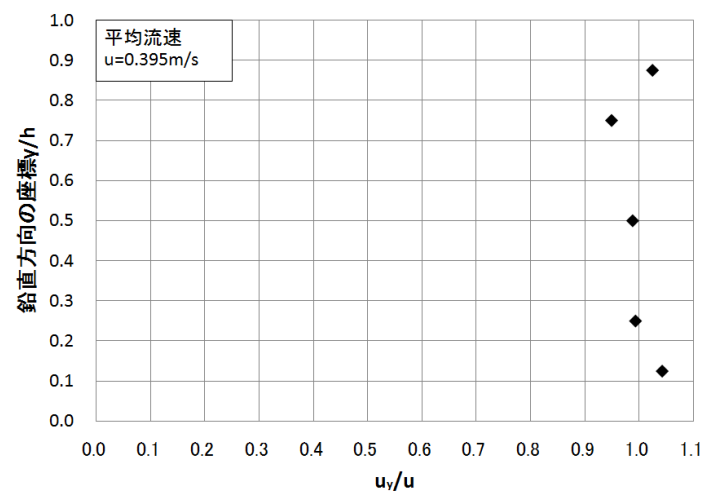

図-7 水路内での水平流速の鉛直分布の検討 結果 $($ 水深 $40 \mathrm{~cm}$, 平均流速 $\mathrm{u}=0.4 \mathrm{~m} / \mathrm{s}$ )

に対して最大となるように固定して，片持ち梁形式 の流体力計を用いて実施した。流体力計の真横には 容量式波高計を設置して, 作用波の水面変動と作用
波力との位相関係が判明するようにした。ここで, 波力の算定については，モリソン式が適用できるも のとした.

各実験で流速は，鉛直断面内の 2 方向の流速が同 時に測定可能な電磁流速計を用いて測定した.

\section{3. 結果および考察}

\section{（1）流速分布}

図-7は，予備実験で水平流速がほぼ $0.4 \mathrm{~m} / \mathrm{s}$ のさ に測定した水深方向の流速分布の結果の代表例を示 す。図中で横軸は各水深位置で測定した流速 $\mathrm{u}_{\mathrm{y}}$ を平 均流速uで除した無次元流速を示し, 縦軸はそれぞ

れ，水路底面を 0 とした時の鉛直方向の測定位置yを 水深hで除した值に相当する.この図より，水深方 向の $\mathrm{u}_{\mathrm{y}} / \mathrm{u}$ は 0.9 1.1 の間に分布しており, 実験水路 での水平流速はほぼ水深方向に一様な流れになって いることが確認できる，本実験では，水路の幅方向 についても同様に水平流速の空間分布を検討してい るが，鉛直方向と同様にほぼ一様な流速分布になっ ていたことを確認しており，ここに付記しておく．

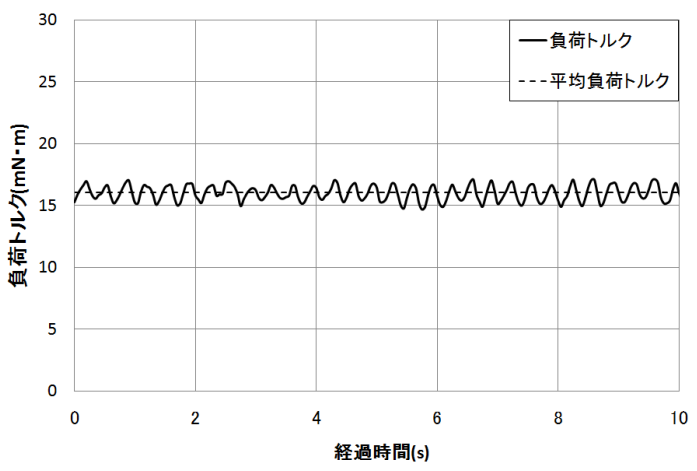

図-8 水車回転時の負荷トルクの測定例 (サボ ニウス型水車, $\mathrm{u}=0.4 \mathrm{~m} / \mathrm{s}$ )

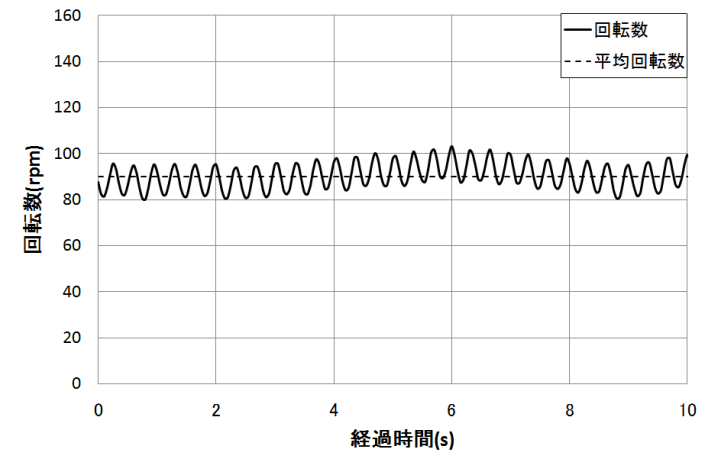

図-9 水車回転時の回転数の測定例 (サボニウス 型水車, $u=0.4 \mathrm{~m} / \mathrm{s}$ )

\section{（2）トルクおよび回転数の代表的な測定結果}

図-8，9は，サボニウス型水車を対象として水深 $\mathrm{h}=40 \mathrm{~cm}$, 流速 $\mathrm{u}=0.4 \mathrm{~m} / \mathrm{s}$, 設定卜ルク $16 \mathrm{mN} \cdot \mathrm{m}$ の条件 


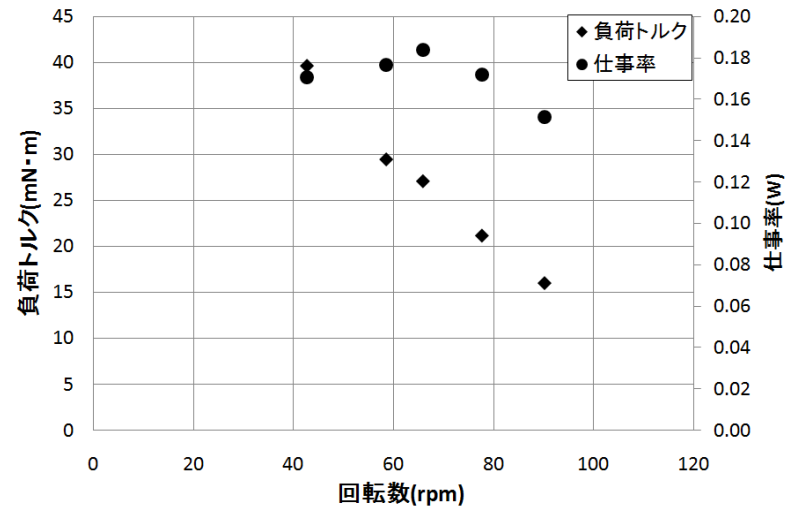

図-10 負荷トルクおよび仕事率 (パワー) と回転数 との関係の測定結果の例

下でのそれぞれ負荷トルクおよび回転数の時系列波 形の測定例を示す。両図より，測定負荷トルクおよ び回転数は，時間的に一定でなく，特定の振れ幅で 振動する時間波形になっていることが分かる。これ は, 回転中の水車の羽根の位置により受ける流体抵 抗が異なるためと考えられる。このような傾向は他 の水車においても確認出来たが， サボニウス型水車 が最も顕著に現れていた．ダリウス型および弧状三 枚羽根型水車の翼が3枚であるのに対し, サボニウ ス型水車の翼は2枚であるため, 流体抵抗が変動す る周期が長くなったことが原因の一つと考えられる。

図-10はサボニウス型水車の水深 $\mathrm{h}=40 \mathrm{~cm}$, 流速 $\mathrm{u}=0.4 \mathrm{~m} / \mathrm{s}$ の時の水車の回転数に対するトルクと仕事 率(パワー)の関係を示す. 負荷トルクと回転数は, 設定トルクごとに時系列波形より平均を読み取った もので，仕事率は回転角速度と負荷トルクの積によ り求めたものである。図より負荷トルクが大きくな ると回転数が下がり，仕事率(パワー)については回 転数が 60 〜 $70 \mathrm{rpm}$ のとに最大となることがわかる。

\section{（3）三種類の水車の性能比較}

図-11，12は，水深 $\mathrm{h}=40 \mathrm{~cm}$ のときの3 種類の水車 の周速比入に対する, トルク係数 $\mathrm{C}_{\mathrm{T}}$ および動力係数 $\mathrm{C}_{\mathrm{P}}$ の変化特性を示す. 動力係数 $\mathrm{C}_{\mathrm{P}}$ および周速比 $\lambda$ の 定義，またトルク特性に対する無次元量 $\mathrm{C}_{\mathrm{T}}$ をあわせ て以下の式 $(1) \sim(3)$ に示す.

$$
\begin{aligned}
C_{P} & =\frac{T_{t} \omega}{0.5 \rho u^{3}(2 R l)} \\
C_{T} & =\frac{T_{t}}{0.5 \rho u^{2}(2 R l) R} \\
\lambda & =\frac{R \omega}{u}
\end{aligned}
$$

これらの式で, $R$ : 翼の回転半径 (水車の半径), $\omega$ : 回転角速度, $l$ : 翼の直立高さ, $u$ : 流速 (平均流速) である。また， $T_{t}$ : 翼で発生する周方向への回転力 に基づく総トルクである.

動力係数 $\mathrm{C}_{\mathrm{p}}$ は，水車による流れのパワーの取得率 あるいは変換効率に相当するもので高い值ほど望ま しい.また，トルク係数は，流れにより得られる回 転トルクの大きさを示すもので, 発電機等の発電負
荷を考えた容量の設定に必要になる。

3 種類の水車では動力係数 $\mathrm{C}_{\mathrm{P}}$ の值が最大となる周 速比 $\lambda$ の值が異なり, 弧状三枚羽根では $\lambda<1$, サボ ニウス型では $\lambda \approx 1$ で最大となる. ダリウス型につ いては，一般に $\lambda$ が 2 以上の高回転数域で, その能 力を発揮すると考えられているが，本実験で製作し た水車の形状では十分な高速域での回転を得ること ができなかったことによるものか， C サボニウス型水車と同程度の性能に留まっている. ダリウス型水車についてはその $\mathrm{C}_{\mathrm{P}}$ が最大となる周速 比やその絶対值ともに今回の実験では不明であり， 今後はより大きい流速值を用いて再検討してみたい。 いずれにしても, ダリウス型水車では相当の高速流 が得られないと, その回転性能が発揮できないよう であり，䄭流時のある潮流に対して適するとは言い 難い面がある。

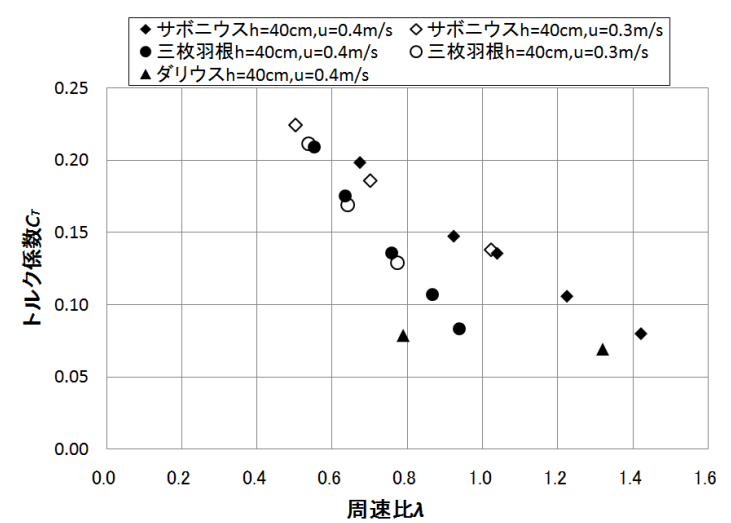

図-11 各水車のトルク係数

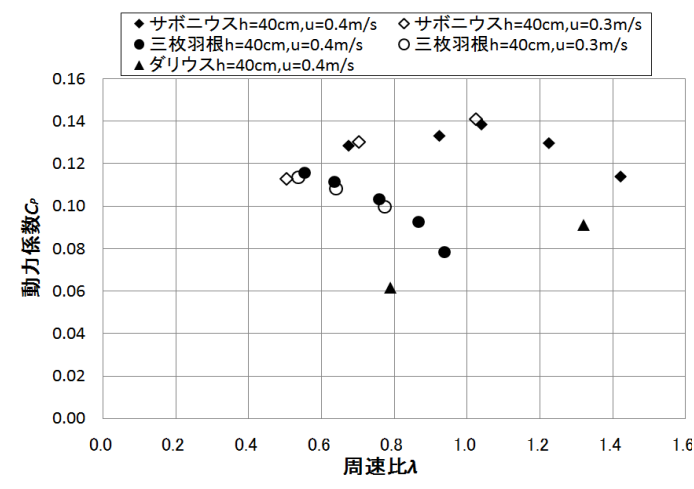

図-12 各水車の動力係数

\section{(4) 水没型と突出型の比較}

図-13はサボニウス型水車の水没時 $(\mathrm{h}=40 \mathrm{~cm})$ と突 出時 $(\mathrm{h}=30 \mathrm{~cm})$ の動力係数 $\mathrm{C}_{\mathrm{p}}$ の比較を示す. 水車の直 立長は，図-2に示すように $35 \mathrm{~cm}$ あ゙あ。現地の来島 海峡では, 最大で $3.5 \mathrm{~m}$ 程度の潮位差があり, 水車の 直立長から考えて有意な潮位差と考えられたため, このような検討を行った。

動力係数 $\mathrm{C}_{\mathrm{P}}$ は, 突出時に水没時と比べて 0.1 0.2 程度低い值を示す.このような傾向は，翼の一 部が水面より出るため, 流れがもつエネルギーの一 部が造波抵抗に使用され動力変換効率が低下したと 考えられる。 


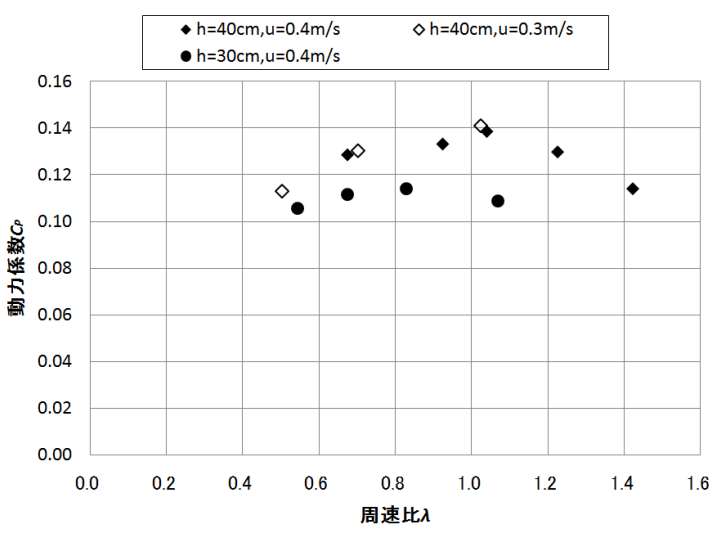

図-13 直立型水車の上端部の空中露出の影響

(サボニウス型水車, 直立長 $35 \mathrm{~cm}$ )

\section{(5) 波が水車の回転に及ぼす影響}

図-14は, 水深 $\mathrm{h}=40 \mathrm{~cm}$, 流速 $\mathrm{u}=0.36 \mathrm{~m} / \mathrm{s}$, 設定卜ル ク $16 \mathrm{mN} ・ \mathrm{~m}$ のときのサボニウス型水車に，通常波浪 の条件に相当寸る周期 $\mathrm{T}=0.9 \mathrm{~s}$, 波高 $\mathrm{H}=4 \mathrm{~cm}$ の波を作 用させた時の水車の回転数の時系列波形を示す. 図 中に示すように波が到達した時点から回転数の変動 がわずかに大きくなっている，波による水粒子水平 速度は, 水面変動と同じ位相で変化することが知ら れており, 波峰が現れる時に定常流に流速が加算さ れるため回転数が上がり, 波谷が現れるときに引き 算されるため回転数が下がるなどの影響を受けたと 考えられる.

また，図-15は，上記した流れの条件で通常波浪

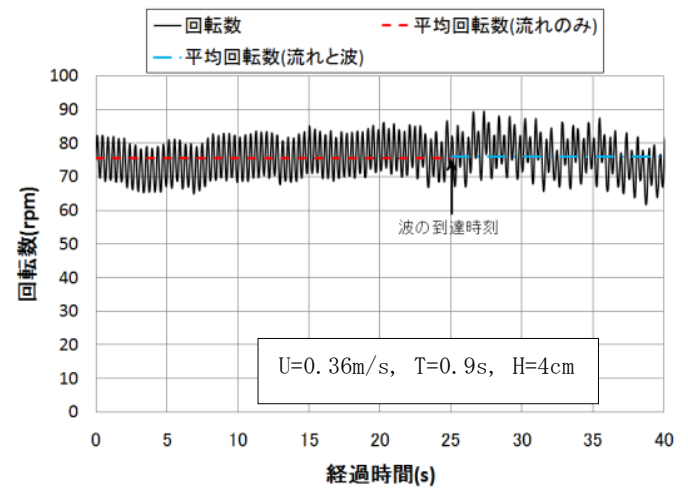

図-14 定常中の水車に波が作用するときの水車 回転数の時間的な変化 (サボニウス型水車)

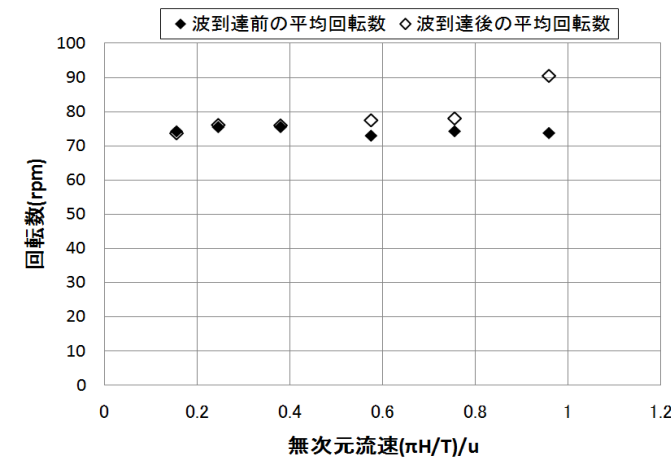

図-15 波高による定常中の水車の回転数の変化 (サボニウス型水車)
から激浪時の波浪を作用させたときの波到達前と到 達後の水車の平均回転数を示す。常時波浪のときは, 波の到達前と到達後で平均回転数にほとんど変化は ないが，激浪時になると到達後の平均回転数が大き くなっている。このことから, 波が潮流による水車 の回転に悪影響を与えることはないと判定される.

\section{（6）流向制御板の有無による水車性能の比較}

図-16, 図-17は，流向制御構造をもつサボニウス 型水車における, 周速比 $\lambda$ に対する, トルク係数 $\mathrm{C}_{\mathrm{T}}$ および動力係数 $\mathrm{C}_{\mathrm{P}}$ の変化特性を示す. 水深 $\mathrm{h}=40 \mathrm{~cm}$ であり, 流速 $\mathrm{u}=0.4,0.3,0.2 \mathrm{~m} / \mathrm{s}$ の 3 種類の流速 条件に対して負荷トルクを変化させて回転性能の測 定を行った. 図中には, 先に示した流向制御板なし のサボニウス型水車 $(\mathrm{u}=0.4 \mathrm{~m} / \mathrm{s})$ の結果を併せて示 寸. 図から明らかなように, 制御板無しの場合に比 べて, トルクは大幅に増加する。 また回転可能域も 高速領域 $\lambda>2.5$ に拡大寸る. 動力係数 $\mathrm{C}_{\mathrm{p}}$ の最大值は, $\lambda \approx 1.5$ の条件で出現し, 流向制御がない場合に比 べて入の大きな条件に移動するとともに, その值自 体も0.5程度と三倍にも増している。 また，両係数 の流速への依存度は低く, 流向制御板を設置した構 造においても, これらの無次元係数が水車の性能評 価に有効なパラメータであることがわかる.

\section{（7）回転翼固定時に水車に作用する潮流力}

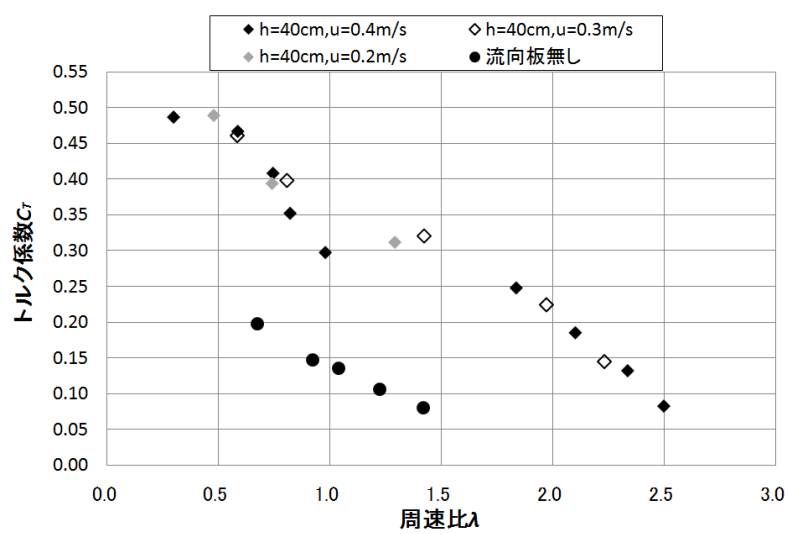

図-16 流向制御板を取り付けたサボニウス型水車 のトルク係数

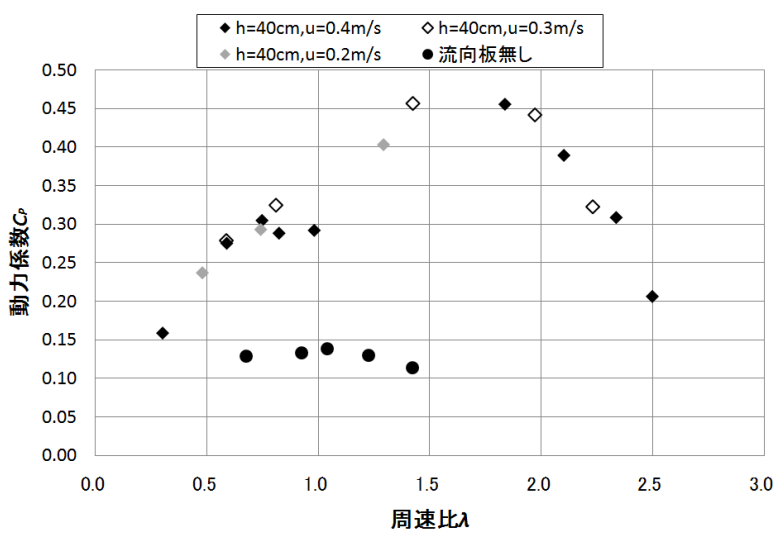

図-17 流向制御板を取り付けたサボニウス型水車 の動力係数 


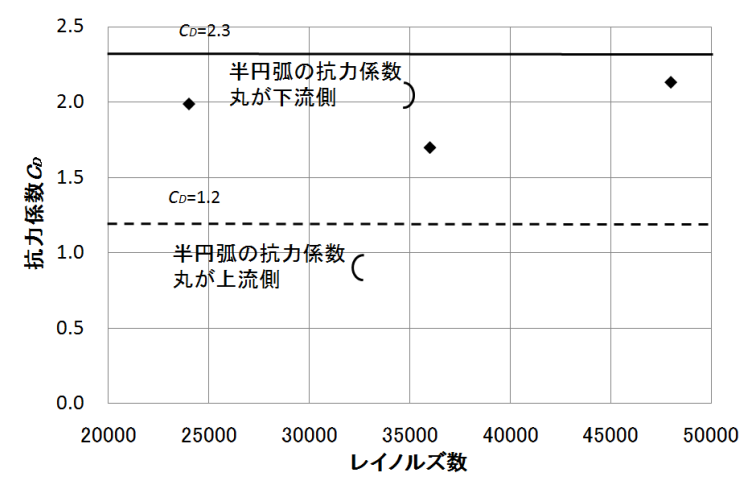

図-18 サボニウス型水車の定常流れの実験から求めら れた抗力係数:羽根固定時

図-18は潮流のみが作用する条件下でのサボニウ ス型水車に作用する抗力の測定結果を抗力係数 $\mathrm{C}_{\mathrm{D}}$ と レイノルズ数（ $\mathrm{uD} / v ， v$ : 動粘性係数）の関係で 示す.

図より，直立型のサボニウス型水車の抗力係数 $\mathrm{C}_{\mathrm{D}}$ は, 2程度の大きさであることが認められる。この抗力 係数の值は，半円断面でその円筒部が上流側に向い ている場合の抗力係数 $\mathrm{C}_{D}=1.2$ と, それが下流側に向 いている場合の $C_{D}=2.3$ との中間的な值に相当してお り, 従来の研究成果とほぼ一致するものと考えられ る.

\section{(8) 回転翼固定時に水車に作用する潮流力と波力}

図-19は，波と流れを受けるときの流体力（波力 と潮流力の合算值）の強度を示す. 流れの条件は, 現地の潮流速に換算して $2.5 \mathrm{~m} / \mathrm{s}$ が波の進行方向と同 方向に作用するものとしてある。このとき，作用波 の波長は，流れの作用により増大することになり， 結果的に波高は低下寸ることが知られている.

この図より，波と流れを同時に受けるときの流体 力は，極小值のピークが流れの影響を受けて負值に ならず，波向き方向に作用する流体力として現れる ことがわかる。

そして，本研究での検討結果によると，波と流れ を同時に受けるときの流体力は，潮流力をベースの 力として，これに時間的に変動する波力成分の正 ピーク值を付加することで近似的に求められること が確認されている. 実際場では流れによる力と波に よる力を加えた外力を設計に用いる必用があり，概 略的には流れのみを受けるときの潮流力と波だけが 作用するときの波力の線形和で作用外力が推定でき る.

\section{4. 結語}

(1) 本研究で対象とした水車の動力係数 $\mathrm{C}_{\mathrm{P}}$ の最大值 はサボニウス型水車で 0.14 , ダリウス型水車で 0.1 ,

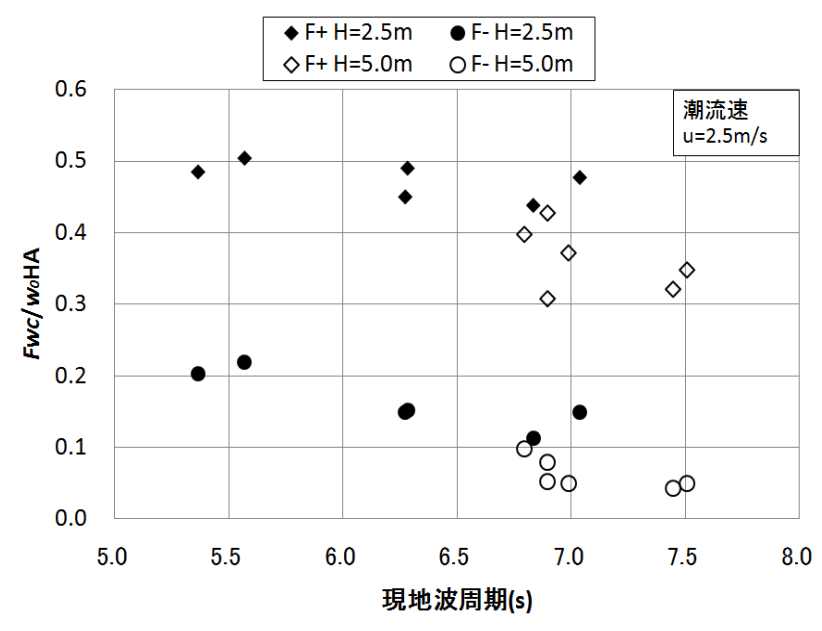

図-19 波と流れを受けるときの作用流体力: 現地換算量 $(\mathrm{F}+$ : 波峰時流体力, $\mathrm{F}-$ : 波谷時流体力, 作用波高を用い た波力強度による無次元化)

弧状三枚羽根型水車で 0.12 程度であることが実験的 に確認できた。ただし，ダリウス型水車では，高い 動力特性を示すと考えられる周速比 $\lambda$ が 2 以上の高 速回転状態を再現できておらず, 今後さらに検討さ れるべき余地がある。

(2) 水車が全体的に水没している場合と頂部が水面 から突出している場合では，突出している場合の方 が，動力係数が低い值を示す.

(3) 流向制御工法として流向制御板を水車の外側に 同心円形式で取り付けた場合，トルク係数および動 力係数は流向制御板なしの結果と比較して三倍にも 増し, また回転可能域も拡大するなど, 非常に効果 的であることが判明した。

(4) サボニウス型水車を, 流れ方向に対して射影面 積が最大となる条件で固定した時の抗力係数 $\mathrm{C}_{\mathrm{D}}$ は 1. 7〜2.1程度である.

(5) 波と流れが作用するときの直立型水車に作用す る流体力は, 両者の影響を考慮した推定が必要であ る. その推定では, 近似的に流れのみが作用すると きの抗力と波のみが作用するときの波力を線形的に 加算する方法を用いることができる.

参考文献

1) Khan, N. I., Iqba1, M. T., Hinchey M. and Masek, M. : Performance of Savonius rotors as a water current turbine, The Journal of 0cean Technology, Vol. 4, No. 2, Maritime and Port Security, pp. 71-83, 2009.

2）経塚雄策・郡司智博・若濱久敬 : 橋脚を利用した潮流 発電について, 日本船舶海洋工学会論文集, 第3 号, pp. 47-52, 2006.

3）木方靖二・塩野光弘：来島海峡におけるダリウス形水 車による潮流発電, 電気学会論文誌, Vol. 112-D, No. 6, 1992. 